\title{
IMPLEMENTASI PMRI DALAM MATERI SIFAT KOMUTATIF DAN ASSOSIATIF PADA BILANGAN BULAT UNTUK LEVEL SISWA SD/MI
}

\author{
Ekasatya Aldila Afriansyah
}

\begin{abstract}
Implementing PMRI in teaching process using a little sheet box and straw as a media for helping students in learning commutative and associative properties in integer numbers is the aim of this study. Design research is used as appropriate means to achieve the aim; conducted in three phases: preliminary design, teaching experiment (first and second cycle), and retrospective analysis. This study enables students to work with contextual situations within integer numbers properties; uses media tool (a straw and little sheet box). Pendidikan Matematika Realistik Indonesia (PMRI) underlies the design of the context and the activities. Sample of population is students from Madrasah Ibtidaiah Negeri 1 Palembang. This study involves fourth grade students, 3 students in first cycle and 36 students in second cycle (4 students were analyzed in detail). The result of this study could show that the activities could bring students' learning from the contextual situation to more formal situation. The activities within this study have been succeed to be implemented in this school so that these activities could be used for the others.
\end{abstract}

Keywords: commutative and associative properties, integer numbers, design research, Pendidikan Matematika Realistik

\section{Pendahuluan}

\section{Latar Belakang Masalah}

Pendidikan Matematika Realistik Indonesia (PMRI) merupakan sebuah inovasi dalam pembelajaran matematika di Indonesia dengan menggunakan beberapa prinsip Realistic Mathematics Education (RME) yang memiliki pandangan tentang apa itu matematika, bagaimana mempelajari matematika, dan bagaimana matematika itu seharusnya dipelajari. RME dikembangkan pertama kali oleh Freudenthal Institute pada tahun 1971 di Belanda. PMRI merupakan pendekatan yang cocok dengan paradigma pendidikan sekarang ini yang lebih memandang siswa sebagai manusia yang memiliki potensi dan kemampuan untuk belajar dan berkembang.

PMRI di Kota Palembang telah dikembangkan sejak tahun 2004. Disini terdapat beberapa sekolah yang bergabung di dalam KKG PMRI (Kelompok Kerja Guru PMRI). Oleh karena itu, peneliti mengambil tempat untuk penelitian ini di Madrasah Ibtidaiah Negeri 1 Palembang. Sejak Mei 2009, peneliti bersama rekan peneliti telah melakukan observasi yang cukup mendalam di sekolah ini.

Materi penelitian diputuskan pada saat proses belajar mengajar dengan cara berdiskusi dengan guru. Di ambil materi sifat komutatif dan asosiatif menyesuaikan dengan kebutuhan siswa. Guru mengharapkan peneliti dapat memberikan cara lain dalam proses belajar mengajar di kelas, dalam hal ini pembelajaran kontekstual.
Hal ini dikarenakan guru yang bersangkutan telah terbiasa memberikan materi berpatokan dengan buku teks yang digunakan. Sejalan dengan Zulkardi (2002), beliau mengatakan bahwa berbagai buku matematika di Indonesia mengandung seperangkat peraturan dan algoritma; buku-buku tersebut kurang aplikasi berupa pengalaman nyata bagi siswa yang membacanya. Pemberian algoritma secara langsung tidaklah selalu baik untuk siswa, siswa hanya akan berpikir abstrak untuk setiap permasalahan dan siswa akan merasa kesulitan ketika dihadapkan permasalahan sehari-hari. Oleh karena itu, proses belajar mengajar menggunakan PMRI diperlukan dalam membuat situasi pembelajaran yang bermakna (meaningful).

Berdasarkan hal di atas, maka penulis tertarik untuk meneliti tentang "Implementasi PMRI dalam Materi Sifat Komutatif dan Assosiatif pada Bilangan Bulat untuk Level Siswa Sekolah Dasar (SD) atau Madrasah Ibtidaiah (MI)".

\section{Rumusan Masalah}

Masalah penelitian ini adalah:

1. Bagaimana cara siswa kelas IV menyadari keberadaan sifat komutatif dan assosiatif dengan menggunakan PMRI?

2. Apakah siswa kelas IV dapat menyelesaikan berbagai persoalan tentang sifat komutatif dan assosiatif dengan menggunakan sedotan dan kotak kertas kecil? 


\section{Tujuan Penelitian}

Tujuan penelitian ini adalah: Mengaplikasikan PMRI dalam proses belajar mengajar pada siswa kelas IV dan menggunakan sedotan dan kotak kecil sebagai alat yang digunakan dalam mempelajari sifat komutatif dan assosiatif.

\section{Kajian Pustaka}

1. Sifat Komutatif dan Assosiatif pada Bilangan Bulat

Sifat komutatif disebut juga sebagai sifat pertukaran. Penjumlahan dua bilangan selalu diperoleh hasil yang sama walaupun kedua bilangan tersebut dipertukarkan tempatnya. Hal ini pun berlaku pada perkalian dua bilangan.

- Untuk setiap bilangan bulat a dan b, selalu berlaku $\mathrm{a}+\mathrm{b}=\mathrm{b}+\mathrm{a}$
- Untuk setiap bilangan bulat $\mathrm{p}$ dan $\mathrm{q}$, selalu berlaku pxq=qxp

Sedangkan untuk sifat assosiatif, sifat assosiatif ini disebut juga sebagai sifat pengelompokan. Sifat ini berlaku pada penjumlahan dan perkalian tiga bilangan bulat, dapat dituliskan sebagai berikut:

- Untuk setiap bilangan bulat $a, b$, dan c, berlaku $(a+b)+c=a+(b+c)$

- Untuk setiap bilangan bulat p. q, dan r, berlaku (pxq)xr=px(qxr)

\section{SK, KD, dan Indikator}

Berdasarkan kurikulum (Kurikulum

Tingkat Satuan Pendidikan Sekolah Dasar dan Madrasah Ibtidaiah, Depdiknas (2006)), topik ini diajarkan di kelas 4 semester 1 (Tabel 1):

\begin{tabular}{lll}
\hline \multicolumn{1}{c}{ Standar Kompetensi } & \multicolumn{1}{c}{ Kompetensi Dasar } & \multicolumn{1}{c}{ Indikator } \\
\hline Bilangan & 1.1. Mengidentifikasi sifat- & 1. Melakukan operasi \\
1. Memahami dan & sifat operasi hitung & penjumlahan, pengurangan, \\
menggunakan sifat-sifat & & perkalian, dan pembagian \\
operasi hitung bilangan & & 2. Menggunakan sifat-sifat \\
dalam pemecahan masalah & & operasi hitung untuk \\
& melakukan perhitungan \\
& secara efisien \\
& 3. Menentukan aturan \\
& operasi hitung campuran \\
& & dan menggunakannya dalam \\
& & pemecahan soal \\
\hline
\end{tabular}

\section{Pendidikan Matematika Realistik Indonesia}

PMRI merupakan adaptasi dari Realistic Mathematics Education (RME) yang merupakan sebuah teori domain-spesifik instruksional, yang menawarkan panduan sebagai instruksi yang bertujuan untuk mendukung mahasiswa dalam membangun atau menciptakan kembali matematika dalam masalah yang berpusat pada pengajaran interaktif, Gravemeijer (1999). Teori ini sangat dipengaruhi oleh konsep Hans Freudenthal tentang "mathematics as human activity". Oleh karena itu, banyak kesempatan yang diberikan oleh guru kepada siswa mereka untuk membangun pemahaman mereka sendiri.

Filsafat PMRI merupakan berdasarkan gagasan-gagasan yang digali dan dikembangkan oleh Hans Freudenthal dalam Zulkardi (2012), terdapat dua pandangan penting, yaitu (1) mathematics must be connected to reality; and (2) mathematics as human activity".

Menurut Freudenthal dalam Gravemeijer (1994) dalam pembelajaran RME terdapat tiga prinsip yang dapat dijadikan sebagai acuan penelitian untuk instructional design yaitu: (1) Guided reinvention and progressive mathematizing, (2) Didactical Phenomenology, dan (3) Selfdeveloped models.

Mendesain serangkai proses kegiatan pembelajaran mulai dari pengalaman berdasarkan kejadian nyata adalah diinspirasi dari lima karakteristik "five tenets" RME oleh Treffers dalam Bakker (2004): (1) Phenomenological exploration, (2) Using models and symbols for progressive mathematization, (3) Using students' own construction and productions, (4) Interactivity, dan (5) Intertwinement.

\section{Metode Penelitian}

\section{Desain Penelitian}

Dalam penelitian ini perlakuannya sebagai berikut :

1). Ada satu kelompok siswa yang terdiri dari 3 orang siswa, yaitu kelompok siswa yang mengikuti proses pembelajaran pada siklus 1. Peneliti disini bertindak sebagai guru. 
2). Pada siklus 2, peneliti bertindak sebagai observer dan guru kelas/pamong yang memberikan materi. Siklus ini terjadi pada satu kelas besar, kelas $4 \mathrm{~A}$.

\section{Subjek Populasi dan Sampel}

Subjek populasi penelitian ini adalah siswa Madrasah Ibtidaiah Negeri 1Palembang, penyesuaian dari materi sifat komutatif dan assosiatif bilangan bulat pada kurikulum pembelajaran di Indonesia. Studi ini merupakan bagian dari suatu design research, bertujuan untuk mendesain suatu pembelajaran yang dapat memberikan pemahaman kepada siswa sebagai modal bagi siswa dalam menghadapi berbagai persoalan sifat komutatif dan assosiatif bilangan bulat.
Penelitian ini dilaksanakan pada siswa kelas IV salah satu Madrasah Ibtidaiah Negeri di Palembang. Sampel diambil secara acak, tanpa mengubah kelas yang ada. Pemilihan sampel dilakukan dengan cara diskusi dengan guru yang bersangkutan. Studi ini telah melibatkan 39 orang siswa yang terdiri dari 2 siklus, siklus 1 kelas kecil (3 orang) dan siklus 2 kelas besar (36 orang).

Design research dipilih sebagai sarana yang tepat untuk mencapai tujuan studi ini. Menurut Gravemeijer and Cobb (2006), design research dilakukan dalam tiga tahap yaitu: preliminary design, teaching experiment $\left(1^{\text {st }}\right.$ cycle and $2^{\text {nd }}$ cycle), dan retrospective analysis.

Berikut adalah tabel dari pembahasan metode pengumpulan dan analisis data (Tabel 3).

Tabel 2. Metode Pengumpulan Data dan Analisis Data

\begin{tabular}{|c|c|c|c|c|}
\hline No. & Data & Aktivitas & Pengumpulan & Analisis \\
\hline 1. & $\begin{array}{l}\text { Desain } \\
\text { Pendahuluan } \\
\text { (preliminary } \\
\text { design) }\end{array}$ & $\begin{array}{l}\text { Studi literatur dan } \\
\text { Desain HLT }\end{array}$ & & \\
\hline \multirow{3}{*}{2.} & \multirow{3}{*}{$\begin{array}{l}\text { Percobaan } \\
\text { Mengajar - } \\
\text { Siklus } 1 \\
\text { (teaching } \\
\text { experiment } \\
1^{\text {st }} \text { cycle) }\end{array}$} & Observasi kelas 4B & $\begin{array}{l}\text { Data video, foto, catatan } \\
\text { peneliti }\end{array}$ & $\begin{array}{l}\text { Analisis norma-norma yang } \\
\text { terjadi di kelas dan memilih } 3 \\
\text { orang anak untuk pilot class }\end{array}$ \\
\hline & & Diskusi dengan guru & Catatan peneliti & Analisis kemampuan siswa \\
\hline & & $\begin{array}{l}\text { Uji coba aktivitas } \\
\text { 1. Aktivitas } 1 \\
\text { 2. Aktivitas } 2\end{array}$ & $\begin{array}{l}\text { - } \text { Data video } \\
\text { - } \text { Foto } \\
\text { - Lembar Kerja Siswa } \\
\text { - Lembar Aktivitas } \\
\text { - } \text { Catatan peneliti } \\
\end{array}$ & $\begin{array}{l}\text { Analisis seluruh data yang } \\
\text { diperoleh }\end{array}$ \\
\hline 3. & $\begin{array}{l}\text { Perbaikan } \\
\text { HLT } \\
\text { (revisiting } \\
\text { HLT) }\end{array}$ & $\begin{array}{l}\text { Perbaikan HLT } \\
\text { (Diskusi dengan } \\
\text { guru dan supervisor) }\end{array}$ & & $\begin{array}{l}\text { Analisis penerapan HLT pada } \\
\text { siklus pertama sehingga } \\
\text { terdapat perbaikan dan } \\
\text { menghasilkan HLT yang lebih } \\
\text { baik }\end{array}$ \\
\hline \multirow{4}{*}{4.} & \multirow{4}{*}{$\begin{array}{l}\text { Percobaan } \\
\text { Mengajar - } \\
\text { Siklus } 2 \\
\text { (teaching } \\
\text { experiment } \\
2^{\text {nd }} \text { cycle) }\end{array}$} & Observasi kelas $4 \mathrm{~A}$ & $\begin{array}{l}\text { Data video, foto, catatan } \\
\text { peneliti }\end{array}$ & $\begin{array}{l}\text { Analisis norma-norma yang } \\
\text { terjadi di kelas dan memilih } 4 \\
\text { orang anak untuk focus group }\end{array}$ \\
\hline & & $\begin{array}{l}\text { Wawancara dan } \\
\text { diskusi dengan guru }\end{array}$ & Data video, catatan peneliti & Analisis background guru \\
\hline & & $\begin{array}{l}\text { Uji coba aktivitas } \\
\text { 1. Aktivitas } 1 \\
\text { 2. Aktivitas } 2\end{array}$ & $\begin{array}{l}\text { - Data video } \\
\text { - Foto } \\
\text { - Lembar Kerja Siswa } \\
\text { - Lembar Aktivitas } \\
\text { - } \text { Catatan peneliti }\end{array}$ & $\begin{array}{l}\text { Analisis seluruh data yang } \\
\text { diperoleh terutama LKS dan } \\
\text { lembar aktivitas pada focus } \\
\text { group }\end{array}$ \\
\hline & & $\begin{array}{l}\text { Wawancara siswa, } \\
\text { guru, dan observer }\end{array}$ & Data video, catatan peneliti & $\begin{array}{l}\text { Analisis kesesuaian HLT dengan } \\
\text { keadaan yang terjadi }\end{array}$ \\
\hline
\end{tabular}


Peneliti mendesain rangkaian pembelajaran yang terdiri dari dua aktivitas inti yakni di aktivitas pertama siswa digiring untuk mengenal media yang akan digunakan sebagai alat bantu dan juga pemberian materi pendahuluan tentang sifat komutatif dan assosiatif, dan dilanjutkan pada aktivitas kedua yaitu aplikasi siswa dalam mengerjakan persoalan-persoalan kontekstual yang diberikan dengan menggunakan bantuan alat bantu yang disediakan. Siswa diharuskan selain dapat mengerjakan persoalan kontekstual tersebut secara tertulis, siswa pun mengerti ketika mengaplikasikannya dengan alat bantu yang telah disediakan (kotak-kotak kecil dan sedotan). $R M E$ atau di Indonesia adalah PMRI mendasari pendesainan konteks dan kegiatan.

\section{Hasil dan Pembahasan Penelitian}

Data yang diperoleh dan dianalisis dalam penelitian ini berupa jalannya proses pembelajaran di kelas dan nilai hasil kerja siswa pada aspek kemampuan penalaran matematik siswa.

\section{Deskripsi Data}

Guru membuka kegiatan kelas dengan penjelasan beberapa contoh persoalan tentang sifat komutatif dan assosiatif pada bilangan bulat yang berhubungan dengan aktivitas sehari-hari siswa. Contohnya:

1. Ketika kalian makan, biasanya apa dahulu yang didahulukan? Nasi dahulu kemudian minum atau minum dahulu baru kemudian makan nasi?

2. Ketika kalian mandi, apa yang kalian dahulukan? Menyiram badanmu terlebih dahulu atau sikat gigi terlebih dahulu?
3. Ketika kalian akan makan malam, menu makan malam kalian selain nasi ada ikan dan sayuran. Yang manakah yang terlebih dahulu kalian makam? Makan ikan dan nasi kemudian sayuran atau makan ikan kemudian nasi dan sayuran?

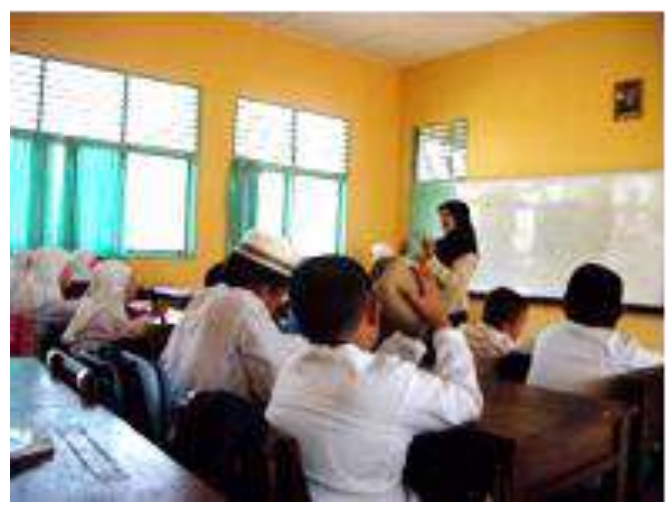

Gambar 1. Guru menjelaskan contoh permasalahan dalam kehidupan sehari-hari

Dari beberapa contoh di atas, guru bertanya kepada siswa, adakah diantara kalian yang dapat menuliskan bentuk matematikanya dari contoh-contoh tadi? (Gambar 1) Kemudian setelah itu, guru mengajak siswa untuk mencari contoh lainnya yang memiliki arti yang sama dengan contoh-contoh sebelumnya.

Berikutnya, guru membagi banyak siswa ke dalam lima kelompok yang terdiri dari empat sampai lima siswa setiap kelompoknya. Guru secara tenang menjelaskan apa yang seharusnya siswa-siswa lakukan dalam berkelompok. Tiap kelompok terlebih dahulu dibagikan lembar kerja kelompok (Gambar 2), sedotan, dan kotak-kotak kecil.

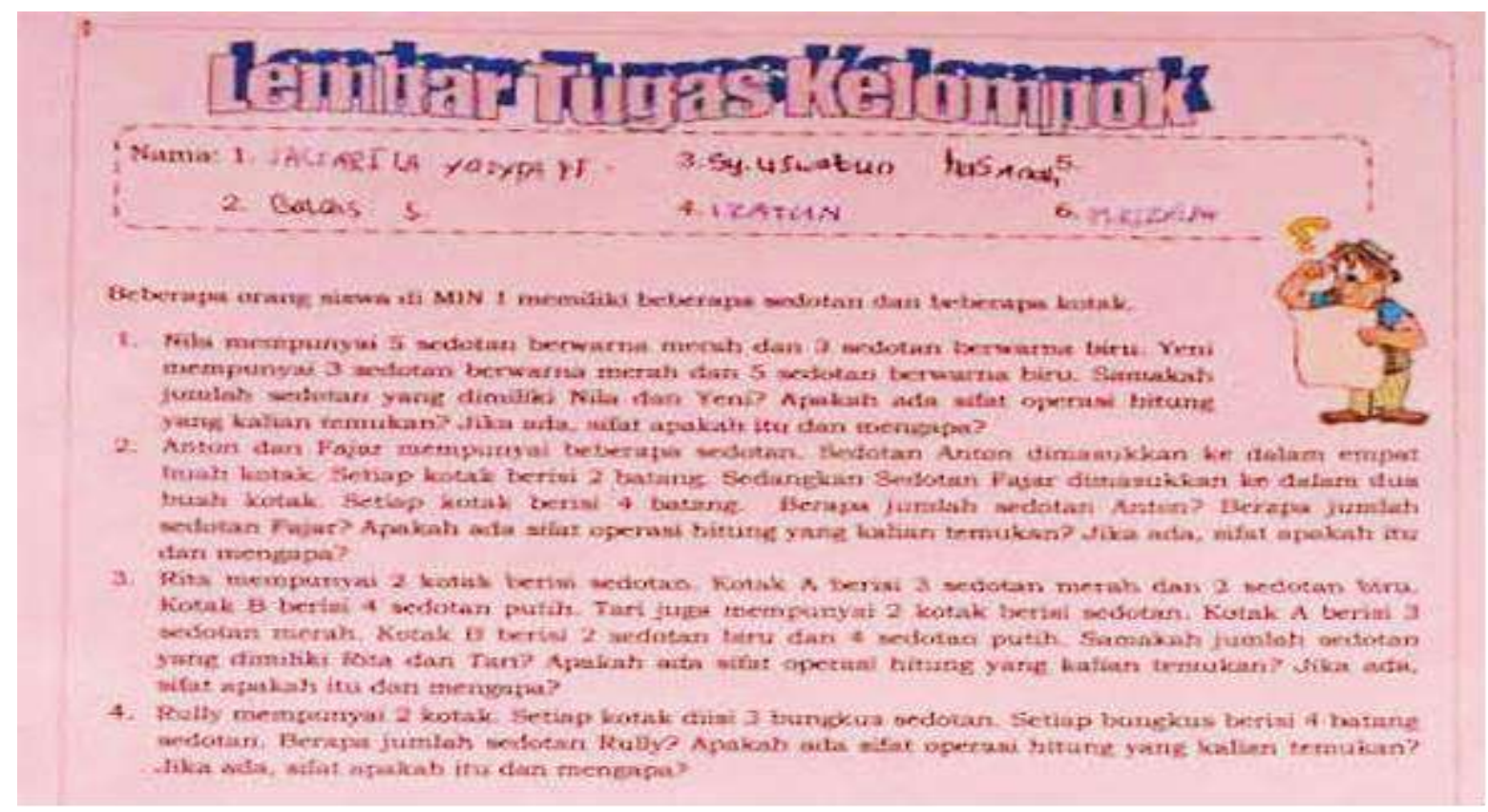




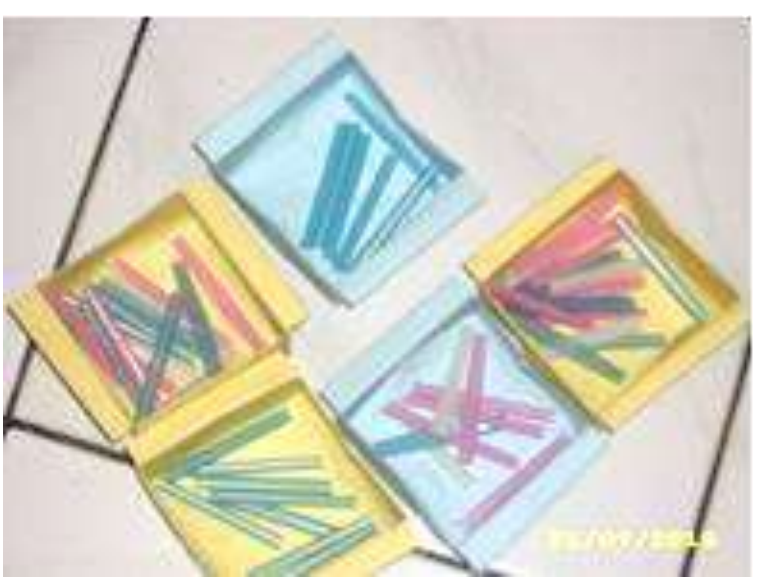

Gambar 3. Sedotan dan kotak-kotak kecil

Sedotan dan kotak-kotak kertas (seperti pada Gambar 3) dipergunakan sebagai alat bantu siswa dalam menjawab lembar kerja kelompok. Selagi siswa bekerja dengan teman kelompoknya, guru mengawasi dan memberikan arahan yang tepat secara berkeliling bagi kelompok yang memerlukan.

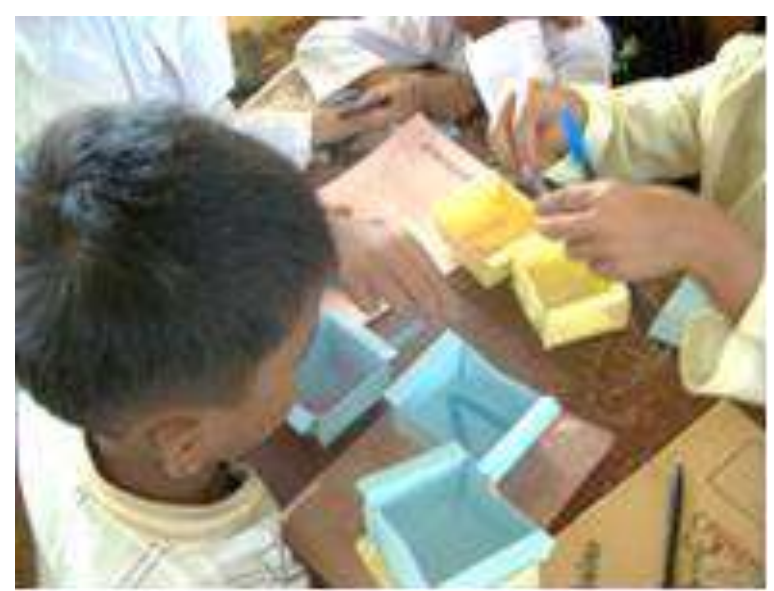

Gambar 4. Siswa bekerja menggunakan alat bantu

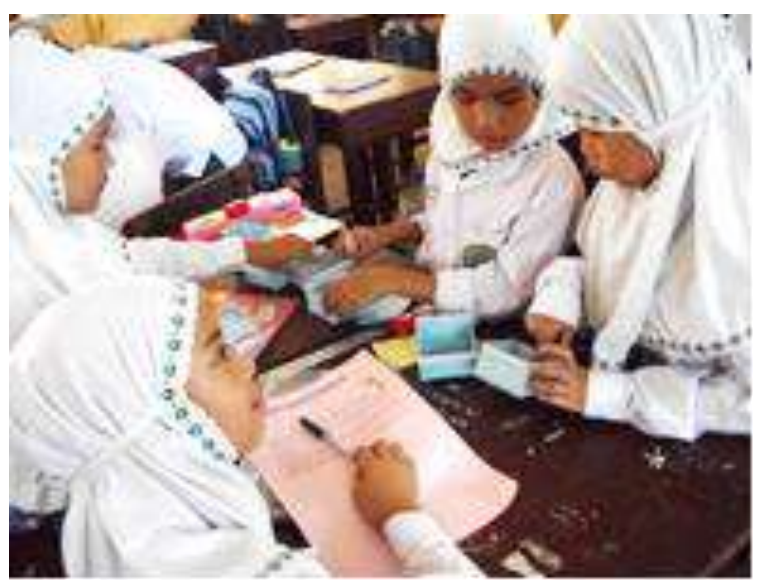

Gambar 5. Siswa saling bantu memberikan penjelasan
Setelah 45 menit berlalu, guru meminta siswa untuk mengumpulkan pekerjaan mereka dan bersama-sama membahas apa yang telah mereka kerjakan. Tiap kelompok memberikan jawaban mereka, dan ketika terdapat perbedaan jawaban, guru tidak langsung memberikan jawaban yang benar tetapi memancing suasana kelas agar terjadi diskusi. Sehingga suasana kelas bermakna dengan adanya interaksi/diskusi antara siswa, tidak hanya interaksi guru dengan siswa saja.

Di akhir pembelajaran, guru bersamasama dengan siswa mencari kesimpulan apa yang telah mereka pelajari pada pertemuan kali ini, yaitu menyimpulkan bahwa mereka telah belajar sifat komutatif dan assosiatif pada bilangan bulat. Formulana adalah $a+b=b+a, \quad a x b-b x a$, $a+(b+c)=(a+b)+c$, dan $\operatorname{ax}(b x c)=(a x b) x c$. Guru juga membantu siswa dalam membuktikan bahwa sifat komutatif dan assosiatif tidak berlaku pada operasi pengurangan dan pembagian.

\section{Analisa Data}

Ketika guru memberikan contoh persoalan yang berkaitan dengan kehidupan sehari-hari, siswa mengerti bahwa itu adalah contoh dari sifat komutatif dan assosiatif. Mereka dapat menyadari apabila terdapat suatu pertukaran antara dua bilangan bulat maka disebut sifat komutatif dan apabila terdapat pengelompokan aktara tiga bilangan bulat maka disebut sifat assosiatif.

Untuk penganalisaan lembar kerja kelompok, guru memberikan empat soal. Sebagian besar kelompok kesulitan untuk menuliskan jawaban mereka, seharusnya guru perlu memberikan arahan lebih jelas sebelumnya. Hal itu juga mungkin terjadi dikarenakan siswa tidak biasa untuk membangun konsep pengetahuan mereka sendiri. Hasilnya adalah mereka kesulitan dalam menuliskan cara bagaimana mereka mendapatkan jawabannya. Mereka mengerti pertanyaannya, menggunakan sedotan dan kotakkotak kecil dengan benar, tetapi ketika guru meminta bagaimana cara mereka mendapatkan jawaban mereka tersebut, mereka kebingungan bagaimana cara mereka menuliskannya pada lembar kerja kelompok. Jadi, beberapa kelompok hanya memberikan jawaban tanpa menuliskan penalaran mereka.

Berikut Gambar 6 dan 7 adalah contoh jawaban siswa: 


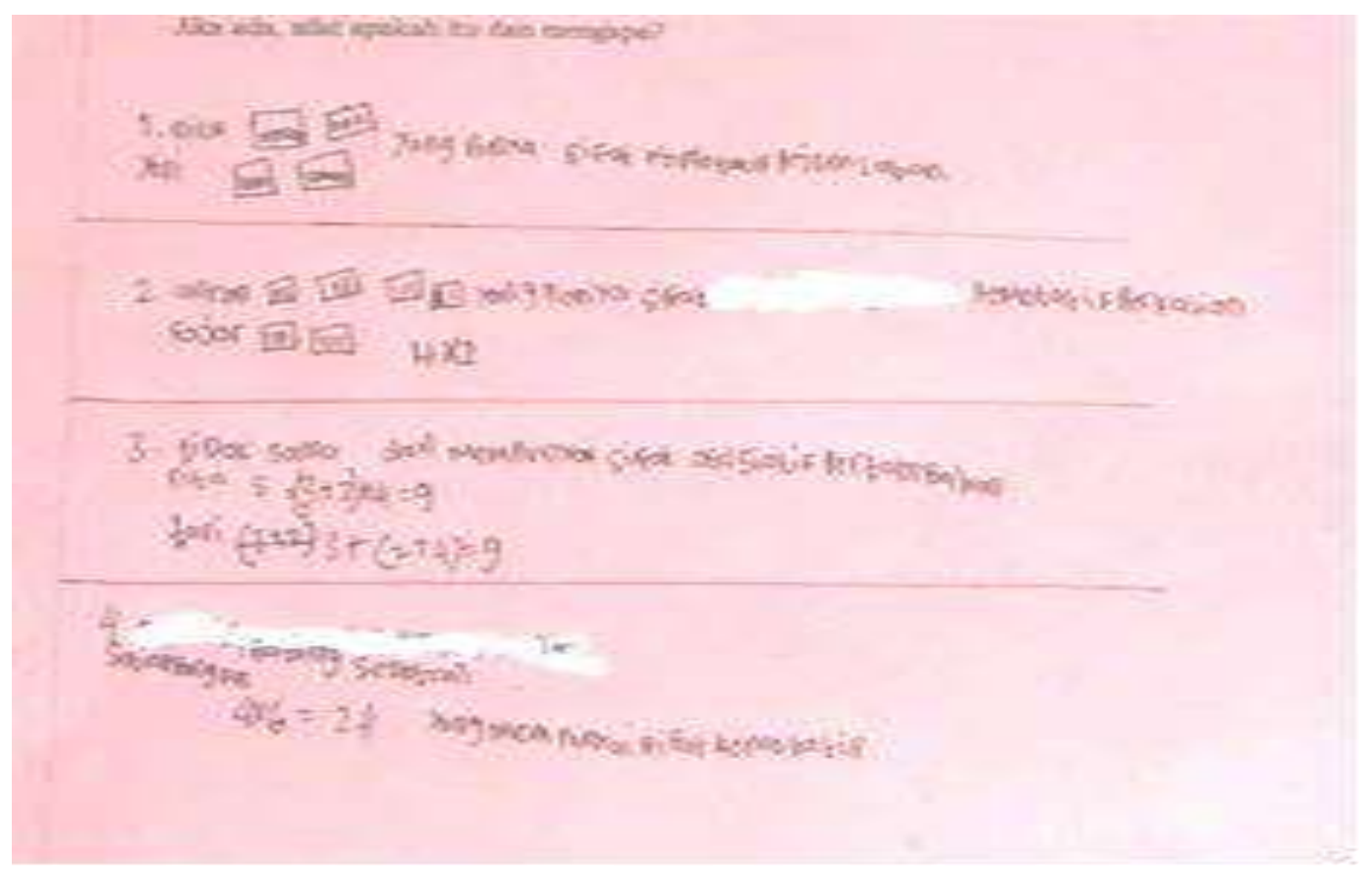

Gambar 6. Contoh Jawaban Siswa 1

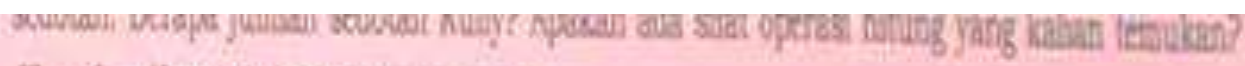

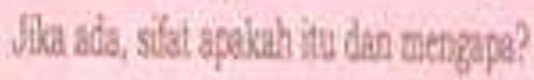

pareon

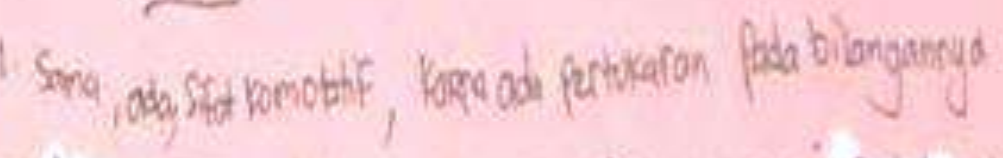

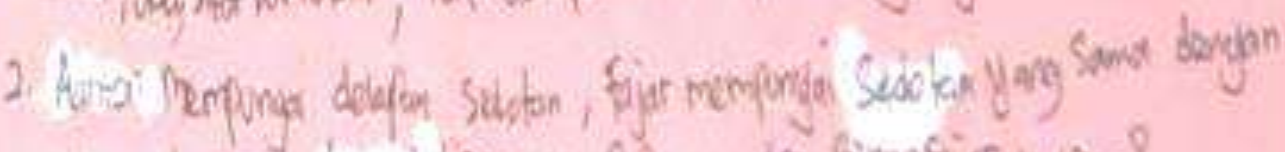

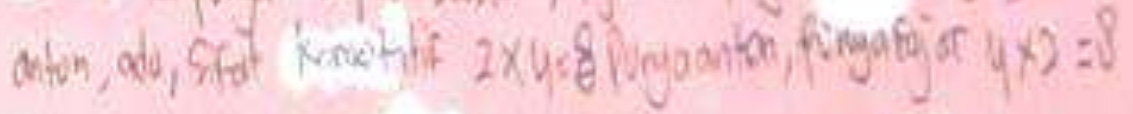

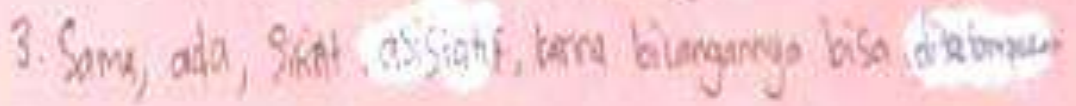

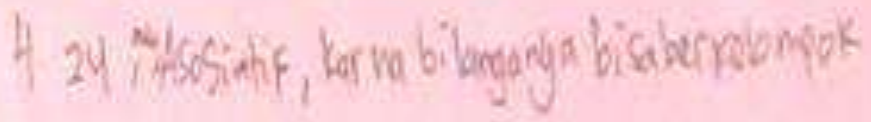


Hampir seluruh siswa bekerja secara aktif di dalam kelompok mereka dan berbagi pendapat satu sama lain. Guru memberikan bimbingan kepada siswa secara berkelompok ataupun individu apabila siswa tersebut menemukan kesulitan selama proses belajar mengajar.

\section{Kesimpulan}

Dari pendeskripsian data dan analisis data di atas, dapat disimpulkan bahwa dalam mempelajari materi sifat komutatif dan assosiatif pada bilangan bulat dengan menggunakan PMRI, guru dapat mengaitkan materi tersebut dengan aktivitas siswa dalam kehidupan sehari-hari dan kemudian secara perlahan mencari notasi formal/bentuk matematiknya. Dengan menggunakan sedotan dan kotak-kotak kecil sebagai alat bantu pembelajaran dapat membantu siswa mengerti dan menyelesaikan sifat komutatif dan assosiatif pada bilangan bulat.

\section{Saran}

1. Bagi guru matematika, PMRI dapat menjadi salah satu alternatif pembelajaran di kelas yang dinilai dapat meningkatkan kemampuan penalaran matematik siswa.

2. Bagi guru matematika, soal-soal latihan yang diberikan jangan dibiasakan dengan soal rutin, tetapi berikanlah soal-soal yang tidak rutin atau soal-soal yang mengandung kemampuan penalaran siswa.

\section{Daftar Pustaka}

Bakker, A. (2004). Design Research in Statistics Education. On Symbolizing and Computer Tools. Amersfoort: Wilco Press.

Depdiknas. (2006). Kurikulum Tingkat Satuan Pendidikan. Depdiknas. Jakarta.

Gravemeijer. K. (1994). Developing Realistic Mathematics Education. Utrecht: Freudenthal Institute.

Gravemeijer, K. (1999). How emergent models may foster the constitution of formal mathematics. Mathematical Thinking and Learning, 1(2), 155-177.

Gravemeijer, K. and Cobb, P. (2006). Design research from the learning design perspective, Educational design research, 1751, London: Routladge.

Zulkardi. (2002). Developing A Learning Environment on Realistic Mathematics Education For Indonesian Student Teachers. Enschede: Twente University.

\section{Riwayat Hidup}

Ekasatya Aldila Afriansyah, S.Si., M.Pd. Dosen Tetap STKIP Garut. S1 Matematika UPI Bandung, lulus tahun 2009. S2 Pend. Matematika UNSRIUtrecht, lulus tahun 2012. 